\title{
Influence of Ammonium Molybdate on Enzymatic Activity and Nodulation in Pigeonpea Grown on Vertisol
}

\author{
Y. P. Swami ${ }^{1 *}$, S. L. Waikar ${ }^{1}$, A. R. Bhosale ${ }^{1}$ and S. C. Sallawar ${ }^{2}$ \\ ${ }^{1}$ Department of Soil Science and Agricultural Chemistry, ${ }^{2}$ Department of Agronomy, \\ Vasantrao Naik Marathwada Agricultural University, Parbhani, Maharashtra, India \\ *Corresponding author
}

\section{A B S T R A C T}

\section{Keywords}

Ammonium molybdate,

Nodulation,

Enzymes, Pigeon pea, Vertisol, Dehydrogenase, Acid and Alkaline phosphatase

\section{Article Info}

\section{Accepted:}

17 January 2021

Available Online:

10 February 2021
A field experiment was conducted during 2018-19 to study the "Effect of application of Ammonium molybdate on enzymatic activity and nodulation in pigeon pea grown on Vertisol" at experimental farm, Department of Soil Science and Agricultural Chemistry, College of Agriculture, Vasantrao Naik Marathwada Krishi Vidyapeeth, Parbhani. The experiment was laid out on Vertisol with five treatment combination replicated four times in randomized block design. The treatment consists of $\mathrm{T}_{1^{-}}$Absolute control, $\mathrm{T}_{2^{-}}$Only RDF (25:50 kg N and $\left.\mathrm{P}_{2} \mathrm{O}_{5} \mathrm{ha}^{-1}\right), \mathrm{T}_{3}-\mathrm{RDF}+$ Ammonium molybdate through seed treatment @1g $\mathrm{kg}^{-1}$ seed, $\mathrm{T}_{4}-\mathrm{RDF}+$ Ammonium molybdate through soil application @ $2 \mathrm{~kg} \mathrm{ha}^{-1}, \mathrm{~T}_{5}$ RDF+ Ammonium molybdate through foliar application @ $0.5 \%$. The results found that the abundant soil enzymatic activity observed in treatment receiving foliar application of Ammonium molybdate along with recommended dose of fertilizer as compare to rest of the treatments. Enzymatic activity of various soil enzymes i.e. dehydrogenase, acid and alkaline phosphatase increased from flowering to pod filling and then decreased at harvesting due to low moisture content in soil. In nodulation number of nodules and nodules weight was increased due to application of RDF+ ammonium molybdate through foliar application followed by the treatment receiving ammonium molybdate + RDF through soil application.

\section{Introduction}

Legume crops require not only adequate macronutrient but also micro nutrient for better growth development and adequate bacterial activity for nodule development. Therefore, an optimum supply of micronutrient under balanced condition is very important for achieving higher productivity. Molybdenum is an important micronutrient leading to poor seed yield of pulses in molybdenum deficient soils. It is an essential component of the enzyme nitrate reductase, which catalyses the conversion of $\mathrm{NO}_{3}$ to $\mathrm{NO}_{2}$ Molybdenum is a structural component of enzyme nitrogenase which is actively involved in atmospheric nitrogen fixation by root nodule bacteria in leguminous crops.

Molybdenum concentrations in legume nodules can be ten times higher than in 
leaves. It also acts in enzymes, which bring about oxidation reduction reaction, especially the reduction of nitrate to ammonia prior to amino acids and protein synthesis in the cells of plant.

Molybdenum is essential for the process of symbiotic and non-symbiotic nitrogen fixation. Molybdenum availability is decreased by application of acid-forming fertilizer such as $\left(\mathrm{NH}_{4}\right) \quad 2 \mathrm{SO}_{4}$ to coarsetextured soil. Boron, cobalt and molybdenum are essential elements for plants and their associated bacteria.

Absence of them may restrict development of free-living rhizobia in the rhizosphere, growth of the host plant and nodulation and impair nodule function. Nodule formation on the roots of green gram through Rhizobium bacteria, fix about $35 \mathrm{~kg} \mathrm{ha}^{-1}$ atmospheric nitrogen (Yadav, 1992). Molybdenum is required for the formation of the nitrate reductase enzyme and in the legume it plays an additional role in symbiotic nitrogen fixation. In enzymes, molybdenum has both structural and catalytically functions and is directly involved in reaction.

These enzyme are nitrate reductase, nitrogenase, dehydrogenase and presumably, sulphite reductase. The functions of molybdenum are therefore closely related to nitrogen metabolism, the molybdenum requirement strongly depends on the mode of nitrogen supply.

\section{Materials and Methods}

A field experiment was conducted during year 2018-19 to study the "Influence of Ammonium molybdate on enzymatic activity and nodulation in pigeon pea grown on Vertisol" at Research Farm of Soil Science and Agricultural Chemistry, Vasantrao Naik Marathwada Krishi Vidyapeeth, Parbhani.

\section{Soil enzymes}

The three important soil enzymes i.e. dehydrogenase, acid phosphatase and alkaline phosphatase play important role in soil microbial respiration and phosphorous mobilization.

\section{Dehydrogenase enzyme activity in soil}

Dehydrogenase enzyme activity in soil samples was measured by reduction of $2,3,5$, triphenyl tetrazolium chloride (TTC) to triphenyl formazan (TPF) using colorimetric procedure of Tabatabai (1969).

\section{Acid and alkaline phosphomonoesterase enzyme activity in soil}

The enzymes are classified as acid and alkaline phosphomonoesterase, because they show optimum activities in their respective $\mathrm{pH}$ ranges. Alkaline phosphomonoesterase activity is derived from microorganisms only, while acid phosphomonoesterase is contributed both by plant roots and soilinhabiting microbes, of the various methods available for assay of phosphomonoesterase activity in soils, the method developed by Tabatabai and Bremner (1969) is the most rapid, accurate and precise method was used.

\section{Soil enzymatic activities status of experimental site}

The data pertaining in table 1 indicates that the soil enzyme Dehydrogenase having (21 $\mu \mathrm{g} \mathrm{g}^{-1}$ soils) value with Acid phosphatase (30 $\mu \mathrm{g} \mathrm{g}^{-1}$ soils) and alkaline phosphatase (42 $\mu \mathrm{g}$ $\mathrm{g}^{-1}$ soils) of the experimental site. At initial stage enzymatic activity of the experimental site soil enzymes i.e. dehydrogenase, acid and alkaline phosphatase was influenced by the application of Ammonium molybdate at flowering, pod filling and at harvest respectively. 


\section{Results and Discussion}

Effect of different treatments of ammonium molybdate on enzymatic activities in soil at critical growth stages of pigeon pea

\section{Dehydrogenase}

The data presented in Table 2 indicated that there was a significant results found in case of dehydrogenase enzyme activity with different treatments of ammonium molybdate at three critical growth stages of pigeon pea. Application of ammonium molybdate through soil @ $2 \mathrm{~kg} \mathrm{ha}^{-1}$ along with $\mathrm{RDF}\left(\mathrm{T}_{4}\right)$ found superior at three critical growth stages i.e. flowering $38.01 \mathrm{\mu g} \mathrm{g}^{-1}$ soils, pod filling 40.13 $\mu \mathrm{g} \mathrm{g}^{-1}$ soils and at harvest $27.72 \mu \mathrm{g} \mathrm{g}^{-1}$ soil and it was at par with the treatment foliar application of ammonium molybdate @ 0.5\% $\left(\mathrm{T}_{4}\right)$. However, the lowest dehydrogenase enzymatic activity observed in absolute control $\left(\mathrm{T}_{1}\right)$.

The research findings confirmed with Dotaniya et al., (2014) observed that different crop growth stages showed different amount of dehydrogenase activity in soil, it might be due to secretion of root exudates and biochemical changes in plant system. More microbial activities increased the Dehydrogenase enzymatic activity in the rhizosphere, due to more availability of food materials for its growth. Similar results confirmed by Kaleeswari (2007).

\section{Acid phosphatase}

The data narrated in Table 2 showed that there was a significant results found in case of acid phosphatase enzyme activity with different treatments of ammonium molybdate at three critical growth stages of pigeon pea. Application of ammonium molybdate through soil @ $2 \mathrm{~kg} \mathrm{ha}^{-1}$ along with $\mathrm{RDF}\left(\mathrm{T}_{4}\right)$ found superior at three critical growth stages i.e. flowering $48.04 \mu \mathrm{g} \mathrm{g}^{-1}$ soils, pod filling 53.15 $\mu \mathrm{g} \mathrm{g}^{-1}$ soils and at harvest $31.18 \mu \mathrm{g} \mathrm{g}^{-1}$ soil and it was at par with the treatment receiving foliar application of ammonium molybdate @ $0.5 \%$ along with RDF $\left(\mathrm{T}_{5}\right)$. However, the lowest acid phosphatase enzymatic activity observed in absolute control $\left(\mathrm{T}_{1}\right)$.

The results supported by the findings of Naseby et al., (2000) stated that the acid phosphatase activity was more dependent upon the nutritional status of the plant. Dotaniya et al., (2014) confirmed that different crop growth stages showed different amount of acid phosphatase activity, it might be due to secretion of root exudates and biochemical changes in plant system. Similar findings confirmed by Kaleeswari (2007).

\section{Alkaline phosphatase}

The data presented in Table 2 indicated that there was significant results found in case of alkaline phosphatase enzymatic activity with different treatments of ammonium molybdate at three critical growth stages of pigeon pea.

Application of ammonium molybdate through soil @ $2 \mathrm{~kg} \mathrm{ha}^{-1}$ along with RDF $\left(\mathrm{T}_{4}\right)$ found superior at three critical growth stages i.e. flowering $62.27 \mu \mathrm{g}_{-1}$ soils, pod filling 67.84 $\mu \mathrm{g} \mathrm{g}^{-1}$ soils and at harvest $44.06 \mu \mathrm{g} \mathrm{g}^{-1}$ soils. It was at par with the treatment receiving foliar application of ammonium molybdate @ 0.5\% $\left(\mathrm{T}_{5}\right)$. However, the lowest alkaline phosphatase enzymatic activity observed in absolute control $\left(\mathrm{T}_{1}\right)$.

The results are in conformity to the findings of Kaleeswari 2007 observed that the enzymatic activity of alkaline phosphatases was significantly improved over control. This might be due to increased microbial and root activities. 
Table.1 Initial (Before sowing) enzymatic properties the experimental soil

\begin{tabular}{|r|c|c|}
\hline Sr.No. & Soil Enzymes & Values $\left(\mu \mathrm{g} \mathrm{g}^{-1}\right.$ soil $)$ \\
\hline 1. & Dehydrogenase & 21 \\
\hline 2. & Acid phosphatase & 30 \\
\hline 3. & Alkaline phosphatase & 42 \\
\hline
\end{tabular}

Table.2 Effect of different treatments of ammonium molybdate on enzymatic activities in soil at critical growth stages of pigeon pea

\begin{tabular}{|c|c|c|c|c|c|c|c|c|c|c|}
\hline \multirow[t]{2}{*}{$\begin{array}{l}\text { Sr. } \\
\text { No. }\end{array}$} & \multirow[t]{2}{*}{ Treatments } & \multicolumn{3}{|c|}{$\begin{array}{l}\text { Dehydrogenase }\left(\mu \mathrm{g} \mathrm{g}^{-1}\right. \\
\text { soil) }\end{array}$} & \multicolumn{3}{|c|}{$\begin{array}{l}\text { Acid Phosphatase ( } \mu \mathrm{g} \\
\mathrm{g}^{-1} \text { soil) }\end{array}$} & \multicolumn{3}{|c|}{$\begin{array}{l}\text { Alkaline Phosphatase } \\
\left(\mu \mathrm{g} \mathrm{g}^{-1} \text { soil) }\right.\end{array}$} \\
\hline & & Flowerin: & $\begin{array}{l}\text { Pod } \\
\text { filling }\end{array}$ & $\begin{array}{l}\text { At } \\
\text { harves }\end{array}$ & Flowerin & $\begin{array}{l}\text { Pod } \\
\text { fillin: }\end{array}$ & $\begin{array}{l}\text { At } \\
\text { harves }\end{array}$ & Flowerin & $\begin{array}{l}\text { Pod } \\
\text { fillin }\end{array}$ & $\begin{array}{l}\text { At } \\
\text { harves }\end{array}$ \\
\hline $\mathbf{T}_{1}$ & Absolute control & 21.96 & 26.2 & 17.36 & 30.40 & 35.65 & 19.24 & 51.31 & 55.40 & 37.53 \\
\hline $\mathbf{T}_{2}$ & $\begin{array}{l}\mathrm{RDF}\left(25: 50 \mathrm{~N}: \mathrm{P}_{2} \mathrm{O}_{5} \mathrm{~kg} \text { ha }\right. \\
\left.{ }^{1}\right)\end{array}$ & 26.19 & $28.9^{\prime}$ & 21.38 & 35.66 & 41.46 & 21.70 & 54.69 & 57.25 & 39.29 \\
\hline $\mathbf{T}_{3}$ & $\begin{array}{l}\mathrm{T}_{2}+\mathrm{Ammonium} \\
\text { molybdate seed treatment } \\
@ 1 \mathrm{~g} \mathrm{~kg}^{-1} \text { of seed }\end{array}$ & 31.47 & 34.5 & 23.86 & 38.67 & 44.11 & 25.31 & 57.06 & 60.40 & 41.87 \\
\hline $\mathbf{T}_{4}$ & $\begin{array}{l}\mathrm{T}_{2}+\text { Ammonium } \\
\text { molybdate soil } \\
\text { application@2 } 2 \mathrm{~kg} \mathrm{ha}^{-1}\end{array}$ & 38.01 & 40.1 & 27.72 & 48.04 & 53.15 & 31.18 & 62.27 & 67.84 & 44.06 \\
\hline $\mathbf{T}_{5}$ & $\begin{array}{l}\mathrm{T}_{2}+\text { Ammoniummolybdate } \\
\text { foliar application @ 0.5\% }\end{array}$ & 35.29 & 39.0 & 25.07 & 45.19 & 47.24 & 28.92 & 60.19 & 63.94 & 43.36 \\
\hline & Mean & 30.58 & 33.7 & 23.07 & 39.59 & 44.32 & 25.27 & 57.10 & 60.96 & 41.22 \\
\hline & $\mathrm{SE}(\mathrm{m}) \pm$ & 0.91 & 0.82 & 0.93 & 0.90 & 1.64 & 1.06 & 1.28 & 1.64 & 1.47 \\
\hline & C.D. at $5 \%$ & 2.80 & 2.52 & 2.87 & 2.79 & 5.04 & 3.28 & 3.94 & 5.05 & 4.53 \\
\hline & C.V \% & 5.93 & 4.84 & 8.07 & 4.56 & 7.38 & 8.42 & 4.48 & 5.38 & 7.14 \\
\hline
\end{tabular}

Table.3 Effect of different treatments of ammonium molybdate on number of nodules per plant of pigeon pea at critical growth stages

\begin{tabular}{|c|c|c|c|c|}
\hline \multirow{2}{*}{$\begin{array}{l}\text { Sr. } \\
\text { No. }\end{array}$} & \multirow[t]{2}{*}{ Treatments } & \multicolumn{3}{|c|}{ No. of nodules plant ${ }^{-1}$} \\
\hline & & Flowering & Pod filling & At harvest \\
\hline $\mathbf{T}_{1}$ & Absolute control & 8.25 & 12.50 & 5.50 \\
\hline $\mathbf{T}_{2}$ & $\operatorname{RDF}\left(25: 50 \mathrm{~N}: \mathrm{P}_{2} \mathrm{O}_{5} \mathrm{~kg} \mathrm{ha}^{-1}\right)$ & 8.75 & 13.50 & 6.75 \\
\hline $\mathbf{T}_{3}$ & 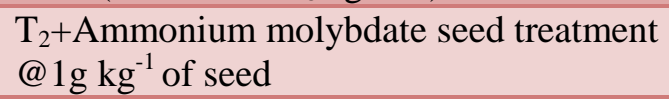 & 10.00 & 13.50 & 6.50 \\
\hline $\mathbf{T}_{4}$ & $\begin{array}{l}\mathrm{T}_{2}+\text { Ammonium molybdate soil } \\
\text { application@ } 2 \mathrm{~kg} \mathrm{ha}^{-1}\end{array}$ & 11.00 & 14.25 & 7.50 \\
\hline \multirow[t]{5}{*}{$\mathbf{T}_{5}$} & $\begin{array}{l}\mathrm{T}_{2}+\text { Ammoniummolybdate foliar } \\
\text { application@ } 0.5 \%\end{array}$ & 11.00 & 15.75 & 9.00 \\
\hline & Mean & 9.8 & 13.9 & 7.05 \\
\hline & SE(m) \pm & 0.43 & 0.51 & 0.52 \\
\hline & C.D. at $5 \%$ & 1.31 & 1.56 & 1.62 \\
\hline & C.V \% & 8.69 & 7.28 & 14.88 \\
\hline
\end{tabular}


Table.4 Effect of different treatments of ammonium molybdate on weight of nodules plant $^{-1}$ of pigeon pea at critical growth stages

\begin{tabular}{|c|c|c|c|c|c|c|c|}
\hline \multirow{3}{*}{$\begin{array}{l}\text { Sr } \\
\text { No }\end{array}$} & \multirow[t]{3}{*}{ Treatments } & \multicolumn{6}{|c|}{ Weight of nodules plant ${ }^{-1}(\mathrm{mg})$} \\
\hline & & \multicolumn{2}{|c|}{ Flowering } & \multicolumn{2}{|c|}{ Pod filling } & \multicolumn{2}{|c|}{ At harvest } \\
\hline & & Fresh & Dry & Fresh & Dry & Fresh & Dry \\
\hline $\mathbf{T}_{1}$ & Absolute control & 8.50 & 2.33 & 19.25 & 3.15 & 5.00 & 1.58 \\
\hline $\mathbf{T}_{2}$ & $\operatorname{RDF}\left(25: 50 \mathrm{~N}: \mathrm{P}_{2} \mathrm{O}_{5} \mathrm{~kg} \mathrm{ha}^{-1}\right)$ & 9.50 & 2.59 & 21.00 & 3.25 & 6.00 & 1.79 \\
\hline $\mathbf{T}_{3}$ & $\begin{array}{l}\mathrm{T}_{2}+\text { Ammonium molybdate seed } \\
\text { treatment @ } 1 \mathrm{~g} \mathrm{~kg}^{-1} \text { of seed }\end{array}$ & 10.00 & 2.64 & 21.00 & 3.55 & 6.50 & 1.86 \\
\hline $\mathbf{T}_{4}$ & $\begin{array}{l}\mathrm{T}_{2}+\text { Ammonium molybdate soil } \\
\text { application@ } 2 \mathrm{~kg} \mathrm{ha}^{-1}\end{array}$ & 11.00 & 2.91 & 22.00 & 3.74 & 7.50 & 1.90 \\
\hline $\mathbf{T}_{5}$ & $\begin{array}{l}\mathrm{T}_{2}+\text { Ammoniummolybdate foliar } \\
\text { application@ } 0.5 \%\end{array}$ & 12.25 & 2.97 & 23.50 & 4.01 & 9.00 & 2.02 \\
\hline & Mean & 10.25 & 2.68 & 21.35 & 3.54 & 6.8 & 1.83 \\
\hline & $\mathrm{SE}(\mathrm{m}) \pm$ & 0.49 & 0.08 & 0.73 & 0.08 & 0.49 & 0.03 \\
\hline & C.D. at $5 \%$ & 1.50 & 0.26 & 2.23 & 0.24 & 1.52 & 0.10 \\
\hline & C.V \% & 9.51 & 6.19 & 6.79 & 4.37 & 14.46 & 3.66 \\
\hline
\end{tabular}

\section{Nodulation in pigeon pea}

The data pertaining in to Table 3 reveals that Among different treatments of ammonium molybdate treatment $\mathrm{RDF}+$ Ammonium molybdate through foliar application @ 0.5\% $\left(\mathrm{T}_{5}\right)$ found superior at flowering (11), pod filling (15.75) and at harvest (9) over rest of treatments and treatment RDF + Ammonium molybdate soil application@ $2 \mathrm{~kg} \mathrm{ha}^{-1}\left(\mathrm{~T}_{4}\right)$ and RDF + Ammonium molybdate seed treatment @ $1 \mathrm{~g} \mathrm{~kg}^{-1}$ of seed $\left(\mathrm{T}_{3}\right)$ found at par with $\left(\mathrm{T}_{5}\right)$. However, least number of nodules per plant was noticed in absolute control $\left(\mathrm{T}_{1}\right)$ at all the growth stages of crop.

The results supported by the findings of Yadav et al., (2017) were tested four levels of molybdenum (Control, 0.5, 1.0 and $1.5 \mathrm{~kg}$ Mo $\mathrm{ha}^{-1}$ ) and results revealed that, application of $1.0 \mathrm{~kg} \mathrm{Mo} \mathrm{ha}{ }^{-1}$ significantly increased nodule number per plant. Deo et al., (2002) reported that number of nodules per plant in chickpea increased with increasing dose of molybdenum. Similar findings confirmed by Yanni (2008), Singh et al., (2008), Bhattacharya and Pal (2001), Bhuiyan et al., (2008).

\section{Weight of nodule per plant}

The data presented in Table 4 indicates that fresh and dry weight of nodules per plant in pigeon pea at three critical growth stages. The results revealed that the maximum weight (both fresh and dry) weight of nodules plant ${ }^{-1}$ was found in treatment receiving RDF + Ammonium molybdate through foliar application@0.5\% $\left(\mathrm{T}_{5}\right)$. Fresh weight- 12.25, 23.50, $9.00 \mathrm{mg}$ and dry weight 2.97, 4.01, $2.02 \mathrm{mg}$ at flowering, pod filling and at harvest, respectively. Over rest of treatments and found at par with treatment RDF + Ammonium molybdate soil application @ 2 $\mathrm{kg} \mathrm{ha}{ }^{-1}\left(\mathrm{~T}_{4}\right)$. However, lowest weight of nodules per plant was noticed in absolute control $\left(\mathrm{T}_{1}\right)$ at all the growth stages of crop.

The findings confirmed with the results of Yadav et al., (2017) were tested four levels of molybdenum (control, 0.5, 1.0 and $1.5 \mathrm{~kg}$ Mo $\mathrm{ha}^{-1}$ ) and results revealed that, application of $1.0 \mathrm{~kg}$ Mo ha ${ }^{-1}$ significantly increased fresh and dry weight of nodules. Similarly, Singh et al., (2015) reported that integrated use of micronutrients (B, Co and Mo) on dry weight of nodules found increased plant $^{-1}$. 
Chakraborty (2009) revealed that the foliar application of Mo was slightly better than soil application in increasing the number of nodules, fresh weight of nodules and dry weight of nodules. Similar results confirmed by the findings of Agarwal (2000), Shivkumar and Kumutha (2003) and Shankhe et al., (2004).

In conclusion the treatment receiving $\mathrm{RDF}+$ Ammonium molybdate through soil application@2 $\mathrm{kg} \mathrm{ha}^{-1}$ showed increased activities of dehydrogenase, acid and alkaline phosphatase, followed by the treatment receiving ammonium molybdate through foliar application @ 0.5 per cent in pigeon pea sown on Vertisol. The treatment receiving ammonium molybdate through foliar application @ 0.5 per cent along with recommended dose of fertilizers significantly enhanced nodulation in pigeon pea. Hence the foliar and soil application of Ammonium molybdate was found to best for improving soil enzymatic activity and nodulation in pigeon pea and ultimately to advancement of the soil health and increasing production.

\section{References}

Agarwal, S. (2000) Response of chickpea (Cicer arietinum L.) To iron and molybdenum fertilization in light textured soil. M.Sc. (Ag.) Thesis, RAU, Bikaner.

Bhattacharya, J. and A.K. Pal (2001) Effect of Rhizobium inoculation phosphorus and molybdenum on the growth of summer green gram [Vigna radiata (L.) Wilezek]. Journal of Interacademicia 5, 450-457.

Bhuiyan, M. M.H., M.M. Rahman, F. Afroze, G.N.C. Sutradhar and M.S.I. Bhuiyan (2008) Effect of phosphorus, molybdenum and Rhizobium inoculation on growth and nodulation of mungbean. Journal of Soil and Nature
2, 25-30.

Chakraborty, A. (2009). Growth and yield of lentil (Lens culinaris L.) as affected by Boron and Molybdenum application in lateritic soil. Journal of Cropland Weed, 5, 88-91.

Deo, C. and M.L. Kothari, (2002) Effect of modes and levels of Mo application on grain yield and protein content and nodulation of chickpea grown on loamy sand soil. Communications in Soil Science and Plant Analysis, 33, 2905-2915.

Dotaniya, M. L., S. K. Kushwah, S. Rajendiran, M. V. Coumar, S. Kundu, and A. S. Rao, (2014). Rhizosphere effect of kharif crops on phosphatases and dehydrogenase activities in a Typic Haplustert. National Academy Science Letters, 37, 103-106.

Kaleeswari, R. K. (2007). Role of phosphatase enzymes in phosphorus nutrition of crops. Agricultural Reviews, 28, 149-153.

Naseby, D. C., Pascual, J. A., and Lynch, J. M. (2000). Effect of bio control strains of Trichoderma on plant growth, Pythium ultimum populations, soil microbial communities and soil enzyme activities. Journal of Applied Microbiology, 88, 161-169.

Shankhe G. M., P. S. Naphade and P. A. Sarap (2004) Effect of boron and Molybdenum on their uptake and yield of groundnut. Agriculture Science Digest 24, 51-53.

Shivakumar, U.I. and K. Kumutha, (2003) Effect of Rhizobium and molybdenum on nodulation yield and yield contributing characters of groundnut. Journal of Ecobiology 15, 451-455.

Singh, D.K., A.K. Singh, S.K. Singh, M. Singh, and O.P. Srivastava, (2015) Effect of balanced nutrition on yield and nutrient uptake of pea (Pisum sativum L.) under indo-gangetic plains 
of India. The Bioscan 10, 1245-1249.

Singh, R.P., J.S. Bisen, P.K. Yadav, S.N. Singh, R.K Singh and J. Singh, (2008) Integrated use of sulphur and molybdenum on growth, yield and quality of black gram (Vigna mungo L.). Legume Research 31, 214-217.

Tabatabai, M.A. and J.M. Bremner (1969) Use of P-Nitrophenyl phosphate for assay of soil phosphatase activity. Soil Biology and Biochemistry 1, 301-307.

Yadav D. S. (1992) Pulse crop. Kalyani publisher, New Delhi. 16, 14-21.

Yadav, A., L.R. Yadav, and S.S. Yadav (2017) Effect of molybdenum on nodulation, total nutrition uptake and protein content of cluster bean [Cyamopsis tetragonolaba] varieties. International Journal of Current Microbiology and Applied Sciences 6, 1939-1944.

Yanni, Y.G. (2008) Performance of chickpea, lentil and lupin modulated with indigenous or inoculated rhizobia micro partners under nitrogen, boron, cobalt and molybdenum fertilization schedules. World Journal of Microbiology and Biotechnology 8, 607-613.

\section{How to cite this article:}

Swami, Y. P., S. L. Waikar, A. R. Bhosale and Sallawar, S. C. 2021. Influence of Ammonium Molybdate on Enzymatic Activity and Nodulation in Pigeonpea Grown on Vertisol. Int.J.Curr.Microbiol.App.Sci. 10(02): 2253-2259. doi: https://doi.org/10.20546/ijcmas.2021.1002.268 